\title{
Do social housing providers across Yorkshire and the East Midlands have effective flood risk management in place when maintaining and repairing their housing stock?
}

Received (in revised form): 15th August, 2008

\section{Scott Kenna BSc Hons}

recently graduated from Nottingham Trent University with a first class honours degree in Building Surveying and now works as a graduate Building Surveyor for Drivers Jonas LLP in Birmingham. His interest in social housing issues and flood remediation came from working as a surveyor for a large East Midlands social housing provider during the floods of 2007.

Correspondence: Scott Kenna, 16 Vicarage Green, Edwalton, Nottingham NG12 4AP, UK; Tel: + 447912 675103; E-mail: scott_kenna@hotmail.com

\section{Abstract}

This paper investigates whether social housing providers across Yorkshire and the East Midlands have effective flood risk management in place to mitigate the impacts of inevitable future flooding. A comprehensive review of current literature highlights a plethora of variables magnifying the risk of future flooding in the UK and a number of measures available to reduce the impacts of future flooding on both property and occupiers. Further research has suggested a lack of preparedness on behalf of the social housing providers in respect of managing the risk of future flooding. In addition, there is limited awareness of flood-resilient repair and a lack of both technical skills and experience available to manage what is a specialist process in a very immature market - flood damage remediation.

Journal of Building Appraisal (2008) 4, 71-85. doi:10.1057/jba.2008.28

\section{Keywords:}

flooding, climate change, future flood risk, social housing, flood resilience, flood resistance

\section{INTRODUCTION}

It is clear that the Earth is experiencing changing climate due to global warming.

'If the trend continues, which is likely, this suggests we will have an increase in flooding over the coming years which has major implications for flood risk management'. (Fowler, 2006)

In 2000, the UK experienced the wettest autumn since records began in 1766 (Met Office, 2000). Some parts of the UK experienced extreme rainfall, three times the average norm, and had an 'expected return period of between 100 years and 200 years' (The Parliamentary Office of Science and Technology, 2000). Approximately 10,000 homes were damaged by the floods at a cost of over £1bn (Environment Agency, 2001). Further flooding occurred in the UK summer of 2007; the UK Met Office reports that rainfall across England between May and July is the wettest since records began (Met Office, 2007). Floods affected 37,000 properties and the cost of damage caused could run to 
$£ 2.7 b n$ (BBC News, 2007a). Simultaneously, signs of neglect are shown by the Department for Environment, Food and Rural Affairs (DEFRA) as it reduces its 20062007 allocation of flood risk management grant to the Environment Agency (EA) from $£ 428 \mathrm{~m}$ to $£ 413 \mathrm{~m}$ (DEFRA, 2007).

The government's Chief Scientific Advisor, Sir David King, declares that the risk of future flooding in Britain due to climate change is increasing:

'in virtually every scenario considered, the risks grow to unacceptable levels'. (King, 2004, p. 2)

King (2004, p. 20) also states that 'the socially disadvantaged will be hardest hit' and those with illness or disabilities will be most susceptible to these risks.

Social housing providers have a legal responsibility to comply with Section 11 of the Landlord and Tenant Act 1985, Section 4 of the Defective Premises Act 1972 and the Decent Homes Standard, as well as a moral responsibility to protect the socially disadvantaged from future flood damage. Practical steps can be taken to reduce the impact, cost and recovery time of flood damage. Flood protection measures such as dryproofing and wet-proofing can be implemented. Additionally, post-flood surveys can be carried out before specifying the standard of repair required for the building and hence provide an assessment of opportunities to reduce the impacts of a future flood event by improving the resilience or resistance of a building (Garvin et al., 2005). For example, closed-cell-type wall insulation and cement:hydrated lime:sand-based plasters instead of gypsum-based plasters can be used.

One of the main conclusions in an independent review of the floods in 2007 recommended that

'...local authorities and housing associations should take a more active role in increasing the uptake of flood resistance and resilience measures, leading by example by repairing their properties with appropriate materials...'. (Pitt, 2007, p. 134)

The UK Government has already identified a crisis involving a shortage of social housing and aims to deliver 'at least 45,000 new social homes' a year by 2010-2011 (Department for Communities and Local Government (DCLG), 2007). Not only will this see increased development of flood risk areas, but this shortage may get even shorter if inevitable future flooding affects large numbers of social housing stock and no action is taken beforehand to reduce its impact.

The impact of global warming on climate distortion is consequentially increasing the frequency of flooding in the UK. As stated previously, the heavy rainfall that led to flooding seen in 2000 had an expected return period of at least 100 years; yet only seven years later this was exceeded, leading to the floods of 2007. Many social housing properties may not have adequate insurance, evident from Hull City Council's decision not to insure its housing stock against flooding. While Hull City Council was allocated $£ 2.15 \mathrm{~m}$ in emergency aid this year to repair flood-damaged social housing (Gray, 2007), the UK Government's recent decision to cut its 2006-2007 flood risk management budget shows that it cannot always be relied upon.

The socially disadvantaged will be most vulnerable to future floods: the majority are either not capable of or cannot afford to implement flood defensive measures before flooding or effectively repair flood damage using flood-resilient methods post-flooding. Hundreds of social housing properties across Yorkshire and the East Midlands were affected by the 2007 floods and 3,500 were affected in Hull alone (Gray, 2007). Social housing providers have two options when repairing the flood damage: to reinstate the 
property to its condition before flooding or to use flood-resilient repairs that will limit the damage caused by future flooding. In addition, effective flood risk management will be required in order to mirror the changes in climate and subsequent flood frequency.

Future flooding is inevitable. Having a home flooded is an incredibly traumatic event, even more so to those that are socially disadvantaged. Occupiers such as the elderly, disabled, people with illnesses and people with low income are particularly vulnerable to flood damage and the health hazards associated with it. The majority will not be able to implement measures to reduce flood damage to homes themselves and therefore need protecting.

\section{INTRODUCTION TO FLOODING IN ENGLAND}

The Concise Oxford Dictionary (Thompson, 1996) defines a flood as 'an overflowing or influx of water beyond its normal confines', otherwise known as inundation where land is affected. There are a number of different sources by which this can transpire:

- flooding from watercourses such as rivers and streams (fluvial);

- surface water runoff (pluvial);

- groundwater inundating or rising into buildings via capillary action;

- blocked or overloaded storm water drainage systems and sewer flooding (Garvin et al., 2005);

- coastal flooding;

- penetrating leakage from services (ie water pipes) and modern appliances.

\section{Autumn 2000 floods}

As previously stated, the autumn of 2000 was confirmed as the wettest since precipitation records began. This period of persistently intense rainfall led to extensive and in some cases repetitive flooding of thousands of homes, many for the first time, in over 700 locations across England and Wales. The EA reported that 68 per cent of these floods emerged as a result of either no flood defence, overtopping of flood defence or outflanking of defences, 18 per cent due to main river flooding and 14 per cent due to inadequate land drainage (Proverbs and Soetanto, 2004). The report 'Lessons learned: Autumn 2000 floods' was produced by the EA in response to minister requests and, among many other issues, highlighted the need to better understand the condition of flood defences in the country coupled with increased investment.

The Deputy Prime Minister John Prescott described the events as a 'wake up call to the impacts of climate change' (Environment Agency, 2001, p. 1). Despite acceptance that rainfall patterns were 'unique', with disparate parallels to any recorded events in a national context, the findings of a report commissioned by DEFRA concluded that the floods of 2000 'cannot in themselves be attributed to climate change' (DEFRA, 2001, p. 2).

\section{Summer 2007 floods}

The period of 'exceptionally heavy' rainfall between May and July 2007 across England and Wales was double the average norm and was subsequently declared the wettest since records began in 1766 (Met Office, 2007). Resultant flooding across the Midlands, Yorkshire and the Humberside in June 2007 and in the South and South West of England a month later caused damage to 48,000 homes and 7,000 businesses; 13 deaths were also associated (Pitt, 2007). The East Riding of Yorkshire and Kingston upon Hull were the 
worst affected, with approximately 15,500 properties flooded and a further 4,000 properties affected in nearby South Yorkshire. It is currently estimated that the events of summer 2007 have cost the insurance industry approximately $£ 3 b n$, "with the average cost of a property flood claim running at $£ 20,000$ ' (ABI, 2007a, p. 1).

Following the floods of 2007, ministers asked Sir Michael Pitt to conduct another 'lessons learned' report - The Pitt Review: Learning lessons from the 2007 floods. The first (interim) of two reports published in December 2007 states that 'a high proportion' of the 2007 floods involved surface water flooding. To the contrary, a report produced by the House of Commons Public Accounts Committee in exactly the same month suggests that ' 80 per cent of flooding in the June 2007 event was the result of urban drainage system failure' (House of Commons Committee of Public Accounts, 2007, p. 3). The omission of flood defences as a key contributor to the floods of 2007 in the interim Pitt Review is also unexpected considering their fundamental role in the floods of 2000 coupled with confirmation that 'the state of flood defences in England has not improved markedly' since (House of Commons Committee of Public Accounts, 2007, p. 3). Although there has been a 40 per cent increase in funding for the EA since the floods of 2000 , only 57 per cent of all flood defence systems have met their target condition, with over half of flood defences in high-risk areas falling short of their target condition. Instead of highlighting this vulnerability to key infrastructure, Pitt (2007, p. 69) states that ' 50 per cent of the raised flood defences [which] were overwhelmed illustrate the extreme nature of the summer's events'. Is it debatable as to how extreme they were when similar levels of rainfall were experienced only seven years earlier in the floods of 2000? In addition to inconsistent causes of the flooding, the credibility of the 'independent' Pitt Review is further questioned by its failure to mention DEFRA's decision to cut the flood risk management budget allocated to the EA at a time of increased flood threat. Despite contradicting news reports from an arguably unreliable source that there had not been a reduction, Environment Secretary Hillary Benn stated the following:

'...the capital budget for investment in flood defence... has not, repeat not, been cut. It has increased over the last decade from $£ 300 \mathrm{~m}$ to $£ 600 \ldots$... No it is not the case that the capital budget for actual investment in flood defence works has been cut. It has not been cut'. (Channel 4 News, 2007)

The DEFRA website clarified:

'We reduced flood risk grant to the Environment Agency by $£ 15 \mathrm{~m}$, from $£ 428 \mathrm{~m}$ to $£ 413 \mathrm{~m}$ or in other words by 4 per cent'. (DEFRA, 2007)

It is evident that answers regarding the causes of flooding in 2007 are not as definitive as those provided by the EA, who conducted the 'lessons learned' report after the floods of 2000. There are many similarities between the two, such as volume and intensity of rainfall-overwhelmed drainage systems in both events, and again the floods cannot be attributed directly to climate change. It is accepted that The Pitt Review is only an interim appraisal produced immediately after the 2007 floods with limited time for reflection, which could restrict its reliability as a source; however, the main reason for its publication 'was to identify those issues which required urgent action' (Pitt, 2007, p. 139).

\section{Responsibility for flood protection/prevention in the UK}

DEFRA are the main government body relating to flood risk management in England, providing legislative framework, policies and funding for the delivery of flood and coastal 
erosion risk management. Operation duties fall to other stakeholders or 'operating authorities' such as the EA, internal drainage boards, local authorities and private landowners (Proverbs and Soetanto, 2004).

The EA is a Non-Departmental Body of DEFRA responsible for managing flood risk arising from designated main rivers and the sea under the Water Resources Act 1991 (Environment Agency, 2001). The Agency is also empowered to perform flood forecasts, disseminate flood warnings to the general public/organisations and provide an overall general supervisory role for all matters regarding flood defence in England and Wales (Proverbs and Soetanto, 2004).

There is a general consensus led by the Director General of the Association of British Insurers (ABI), Stephen Haddrill, and advocated by several other sources, that the UK Government is ineffectively tackling the issue of increased flood threat:

'This summer's devastating floods highlight the urgent need for a long-term strategy based around more investment, national co-ordination and better planning of land use'. (The Independent, 2007)

The Director General of the ABI is, however, very likely to have his own personal agenda, considering the insurance industry has recently been hit for $£ 3 \mathrm{bn}$. Regardless of performance levels from the UK Government to provide flood protection in the UK, Pitt (2007, p. 122) argues that 'responsibility does not lie with the government or other organisations and authorities alone' and that a more integrated approach between all parties, including communities and individuals, should be adopted.

\section{IMPACTS OF FLOODING}

It is argued that flood damage causes more destruction than any other form of natural disaster (Soetanto et al., 2002). Proverbs and Soetanto (2004) classify the damage caused by flooding into two generic groups, namely direct damage (physical damage caused to buildings or human health) and indirect damage (diminished industrial or business output). Additionally, damage caused by flooding can also be generalised as tangible losses (those with financial worth such as cost of repair) and intangible losses (arbitrary in nature such as detriment to health). As with any other natural disaster:

\footnotetext{
'Damage caused by disasters is highly dependent on the scale and nature of that disaster. Here, the damages caused to a property are dependent on the flood characteristics, in terms of depth, velocity flow, contaminant content and time duration'. (Soetanto et al., 2002, p. 2)
}

\section{Damage to residential property}

The porous nature and common weak points associated with residential buildings provide minimal resistance to the ingress of water during a flood. As mentioned previously, the characteristics of floodwaters greatly influence the nature and extent of flood damage caused. The scale of damage is significantly dependent on the depth of floodwaters:

(1) Floodwaters below ground floor level may cause soil erosion beneath foundations, leading to subsidence or differential settlement, heave action (ie volumetric expansion of the ground causing uplift forces and subsequent cracking to the floor immediately above as it fails in tension), saturation of timber components such as wall plates/joists that may cause warping or subsequent formation of rots/moulds, corrosion of metal fixings and joist hangers, etc. 
(2) Once levels rise above the ground floor, then the extent of damage can increase considerably when fixtures, fittings, contents, services and other areas of the superstructure become affected. In addition to that caused at below ground level, damage may be caused to services such as water, gas and electricity, low-level boilers, telecommunications wiring, carpets, timber-based kitchen units, internal finishes such as spalling of paintwork or debonding of tiles, saturated internal joinery such as doorframes/ skirting/timber floors causing warping, formation of harmful moulds, loss of structural integrity, etc. The majority of these may be damaged to the point of destruction.

(3) Floodwaters that reach half a metre and above inside a residential property will affect higher units, electrical services and appliances as well as causing all the damage noted previously. The potential formation of differential heads greater than $0.6 \mathrm{~m}$ may lead to structural damage of the property such as cracked masonry, rotation of walls, etc.

In addition to flood depth, the characteristics of floodwaters such as velocity, containment content and time duration can all have a substantial impact upon the extent of damage caused. For example, floodwaters with high salt content will facilitate the corrosion of metal fixings/joist hangers and highly contaminated floodwaters in a building (ie containing sewage matter) will almost certainly demand an extensive decontamination process prior to any remediation. High-velocity floodwaters may increase soil erosion beneath foundations and the potential of structural instability. Increased exposure to floodwaters will lead to saturation of building materials that may either increase the likelihood for water to travel higher up the building via capillary action or increase the probability for frost damage to occur. Drying out times will certainly be increased.

The insurance industry estimates that the average cost of flood damage remediation of a building following a flood depth of $1,000 \mathrm{~mm}$ is $£ 22,000$, with a further $£ 13,000$ on average required to replace personnel belongings (Garvin et al., 2005).

\title{
Impact upon occupiers of flood-damaged housing
}

Although the intangible effects of flooding cannot be quantified, they are as equally traumatic as direct effects (Proverbs and Soetanto, 2004). This view can be gauged from a series of quotes during the floods of 2007 :

\footnotetext{
'Paul Hendy, a specialist floods advisor to Hull City Council, says hundreds of people are suffering trauma-like symptoms six months on from the floods'. (BBC News, 2007a)
}

\begin{abstract}
'Some people also reported physical health problems, including sickness, diarrhoea, asthma, sore throats, cold sores and bad chests, which many attributed to the damp living conditions and continuing contamination of their homes'. (Pitt, 2007, p. 23)
\end{abstract}

'Would not wish what I continue to go through to my worst enemy'. (Sheffield Forum, 2007)

Flooding events can have a significant effect on people's health (waterborne infections such as E. coli, hepatitis, etc) and, as stated in the summary of the 2007 floods, can result in the loss of lives. There will be considerable amounts of stress associated with the flooding of one's home and witnessing personal belongings being destroyed. This stress will be further magnified for those one in four people who do not have contents insurance in the UK (ABI, 2003).

\footnotetext{
'Having no cover cost me dearly... It was an expensive oversight'. (Womack, 2007)
} 
It is clear that disrupted living patterns associated with moving into temporary accommodation to allow adequate drying and remediation of flood-damaged property is also a stressful experience. It is estimated that 3,000 people are living in caravans across Hull and East Yorkshire alone after being flooded out of their homes in 2007 (BBC News, 2007b). At the same time, this stimulates further fear of homes being looted in their absence and creates animosity within cramped families who get 'at each others throats all the time' (Pitt, 2007, p. 23). The fact that people are still unable to live in their properties following flooding in Carlisle two and a half years ago (Proverbs, 2007) indicates that the stressful effects of a flood event are long withstanding. Alternatively, those who continue to live in the upstairs of flood-damaged properties without disrupted services such as gas, water, electricity, etc and are bordered by contaminated floodwaters have an equally distressing experience.

The Government's Chief Scientific Advisor Sir David King argues that 'the socially disadvantaged will be hit hardest' (King, 2004, p. 20). Occupiers of social housing include the elderly, disabled, people with illness and people with low income among others. King (2004, p. 20) goes on to state:

'People who are ill or have disabilities will be more vulnerable to the effect of a flood and to health risks due to polluted floodwaters'.

This view is shared by Sir Michael Pitt, who claims that 'some vulnerable people were unable to protect themselves or their possessions' during the 2007 floods. Parrett (2006) states that the damage caused by a flood is also dependent on the pre-existing condition of a property before the flood event. Concurrently, the Housing Green Paper published in 2000 identified the general condition of social housing as poor:

'Too many are in poor accommodation. Years of underinvestment in social housing have left a $£ 19 \mathrm{bn}$ repair backlog'. (DETR, 2000, p. 1)

It may also be proffered that the socially disadvantaged are less able to maintain their property or identify and report on disrepair to their landlord. In response, the government committed to bring 'all social housing up to a decent standard in 10 years [by 2010]' (DETR, 2000, p. 11) where a decent standard is defined as 'one which is wind and weather tight, warm and has modern facilities' (The Decent Homes Standard, 2008). Huge resources have been allocated to the ongoing decent homes works in order to meet the standard by 2010 . This means that there are still social housing properties yet to be bought up to standard, which may increase damage caused by flooding. There will also be enhanced stress for those residents who have witnessed long-awaited improvements (kitchen, bathroom and heating improvements as well as repair works) under the scheme destroyed by flooding.

A review of housing supply carried out by Kate Barker in 2004 has already demonstrated that the demand for social housing far outstrips supply:

'An increase in supply of social housing of 17,000 homes each year is believed to be required to meet the needs...There is also a case for provision at up to 9,000 a year above this rate in order to make inroads into the backlog of need'. (HMSO, 2004, p. 5)

This shortage of social housing not only means that alternative accommodation for flood victims will be difficult to find, but also that the limited social housing available to the socially disadvantaged will get even scarcer. In addition to the aforementioned support for Sir David King's statement that the socially disadvantaged will be affected the most, the majority may not have adequate contents insurance either. The ABI state that 'under half 
of low income households hold home contents insurance' (ABI, 2007b). In other words, more than half of low-income households do not actually have contents insurance. Simultaneously, The General Household Survey conducted in 2001 reports that the average weekly income for owner-occupied households is $£ 600$, with low average weekly incomes of $£ 208$ and $£ 216$ associated with tenants of council housing and housing associations, respectively (Harriott and Mathews, 2004). With the possession of knowledge that many social housing occupiers do not have contents insurance, social housing providers like Hull City Council are promoting flooding advice such as 'Future planning — thinking ahead' (Hull City Council, 2008) urging residents to consider obtaining adequate insurance. This information, however, does seem hypocritical given the fact that Hull City Council failed to adequately insure their housing stock against flooding and had to be allocated $£ 2.15 \mathrm{~m}$ in emergency aid by the government after the flood events of 2007 affected approximately 3,500 council homes (Gray, 2007).

\section{FUTURE FLOOD RISK IN THE UK}

It is estimated by the Public Accounts Committee that currently 2.1 million properties with a total value of $£ 200 \mathrm{bn}$ affecting 4.3 million people in the UK are located within flood risk areas (House of Commons Committee of Public Accounts, 2007). Similar to the flood risk maps produced by the EA and many other flood risk estimates, these figures could be significantly magnified if the future impacts of climate change and other independent variables were considered when estimating flood risk in the UK (OPDM, 2004).

\section{Climate change}

Chief Scientific Adviser to the UK Government and Head of the Office of Science and Technology, Sir David King, commissioned a study into the effects of climate change on flood frequency and intensity in the UK. The Foresight Future Flooding report was subsequently compiled by over 60 leading experts and 'constitutes the most wide-ranging analysis of the problem of increasing flood risk that has ever been made in the UK and possibly internationally'. (King, 2004, p. 2)

The report clearly attributes the fabrication of greenhouse gases with climate distortion and flood risk. It considers four different scenarios for predicting the future effects of flooding: high greenhouse gas emissions, medium-high greenhouse gas emissions, mediumlow greenhouse gas emissions and low greenhouse gas emissions. King (2004, p. 2) states that 'in virtually every scenario considered, the risks [of flooding] grow to unacceptable levels'. The report estimates that average annual flood damages could increase by between 2 and 20 times by the end of the century and that the number of homes vulnerable to flooding could rise from 1.5 million to 3.5 million by 2080 (Pound, 2007).

The UK Government has responded to the threat of climate change caused by excessive $\mathrm{CO}_{2}$ emissions through The Energy White Paper published in July 2007, which set a target to reduce $\mathrm{CO}_{2}$ emissions to 60 per cent of 1990 levels by 2050 (DTI, 2007, p. 192). Simultaneously, and despite the fact that 40 per cent of all EU energy consumption is attributable to buildings (European Commission, 2006), the Minister of Housing for the UK Government, Yvette Cooper, has set a contradictive target to build three million new homes by 2020 (DCLG, 2007).

\section{Increased development of flood risk sites}

Despite the known threat of flooding, 133,600 homes have been constructed on flood risk sites from 1996 to 2005 (Wright, 2007). There are no available data on the potentially 
huge number of homes that have been built against EA advice during the same period. It is inevitable that building on flood risk sites will amplify the extent of damage caused next time a flood occurs, as Philip Eden of the Royal Meteorological Society states:

'perhaps we should let the flood plains do their job, after all they are called flood plains because they flood'. (Channel 4, 2007)

In response, the government have tightened planning policy with regard to the development of flood risk sites through the introduction of PPS 25: Development and Flood Risk. This national policy applies a Sequential Test that requires the developer to demonstrate that there are no reasonably available sites in flood zone 1 (low probability of flooding) before they can develop on a flood zone 2 (medium probability) or flood zone 3 site (high probability of flooding) (DCLG, 2006). As a result, local planning authorities can discourage development of flood risk sites.

Such intervention is, however, limited by the fact that the majority of land in flood zones 1 and 2 is greenbelt land and the development of this land would greatly contrast with guidance set out in PPS 3: Housing Provision, which pushes Brownfield land forward for development and advocates making the best use of space to meet housing trajectories. Pitt (2007) adds that the inclusion of an 'exception test' in PPS 25, where development can proceed in flood risk areas for exceptional reasons, could be viewed as a potential 'get-out clause' for local planning authorities. In contrast to the government's approach to tighten development of flood risk sites through PPS 25 and numerous recommendations by climate change experts that the development of flood risk sites should cease, reports suggest that the government is seeking to develop infrastructure on the Thames Gateway in East London (Channel 4, 2008). After unveiling the government's new Housing Green Paper in July 2007, Yvette Cooper publicised the need for a considerable increase in house building in order to satisfy housing demand and

'...insisted that it was inevitable that some of these new homes would be built on flood plains and warned critics not to "play politics" with the issue'. (Wilson, 2007)

Darren Johnson, Chairman of the London Assemblies and Environment Committee, responded by stating:

'If you were to look at a map and think where was the best place in Britain to develop, you wouldn't be looking at the Thames gateway area'. (Channel 4, 2008)

It is proffered that consistent urbanisation of land has reduced the grounds' natural ability to infiltrate surface water and hence has increased the likelihood of surface water flooding. Pitt (2007) adds that large developments and an accumulation of minor works such as driveways and paving using permitted development rights under the Town and Country Planning Order 1995 is enhancing the problem.

\section{Flood defence}

Flood defence systems have a fundamental role in reducing the risk of flooding in the UK (Parrett, 2006). The 'lessons learned' report produced by the EA after the 2000 floods stated that the shortfall in investment of flood defence works was estimated at $£ 100 \mathrm{~m}$ per annum. The flood risk management budget was subsequently increased by over $£ 100 \mathrm{~m}$ from $£ 200 \mathrm{~m}$ in $2000-2001$ to $£ 303 \mathrm{~m}$ in 2002-2003 (Figure 1; House of Commons Committee of Public Accounts, 2007). The EA received further increases in funding up to 
$£ 550 \mathrm{~m}$ in 2005-2006 but confirmed that the 2006-2007 flood risk management budget allocated to them by DEFRA was cut by $£ 14.9 \mathrm{~m}$ at a time where future flooding was imminent.

Despite this 40 per cent increase in funding to the EA (in real terms over the five years), half of flood defences in high-risk areas fall short of their target condition and, as stated previously, have not improved markedly since the floods of 2000 (Figure 2; House of Commons Committee of Public Accounts, 2007).

It was claimed by Jill Craig of the Royal Institution of Chartered Surveyors that the government's decision to cut spending on flood defences in 2006-2007 was 'terribly short-sighted' (Wilson, 2007). While it is hard to form any other opinion, does a $£ 14.9 \mathrm{~m}$ budget cut amount to the poor conditions of flood defences currently present when spending over the last seven years has met and exceeded levels initially requested in the EA's report in 2000? An analysis of how the flood risk management budget is distributed by the EA highlights the fact that a large proportion of money is spent on administration and development proposals rather than on actually improving flood defences. In deciding

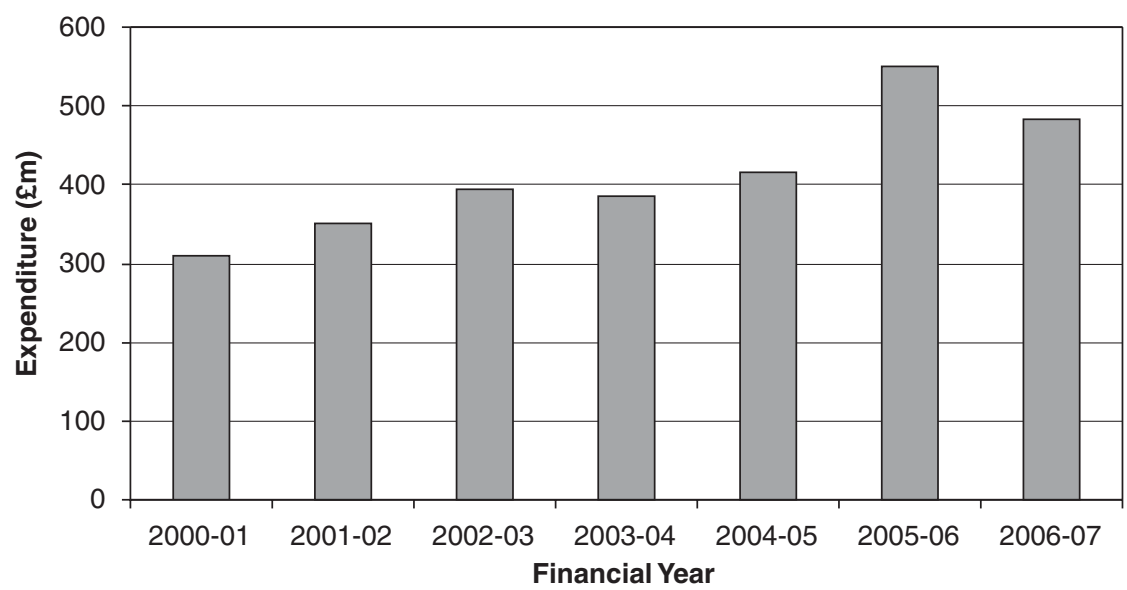

Figure I: Estimated expenditure by the EA

Source: House of Commons Committee of Public Accounts

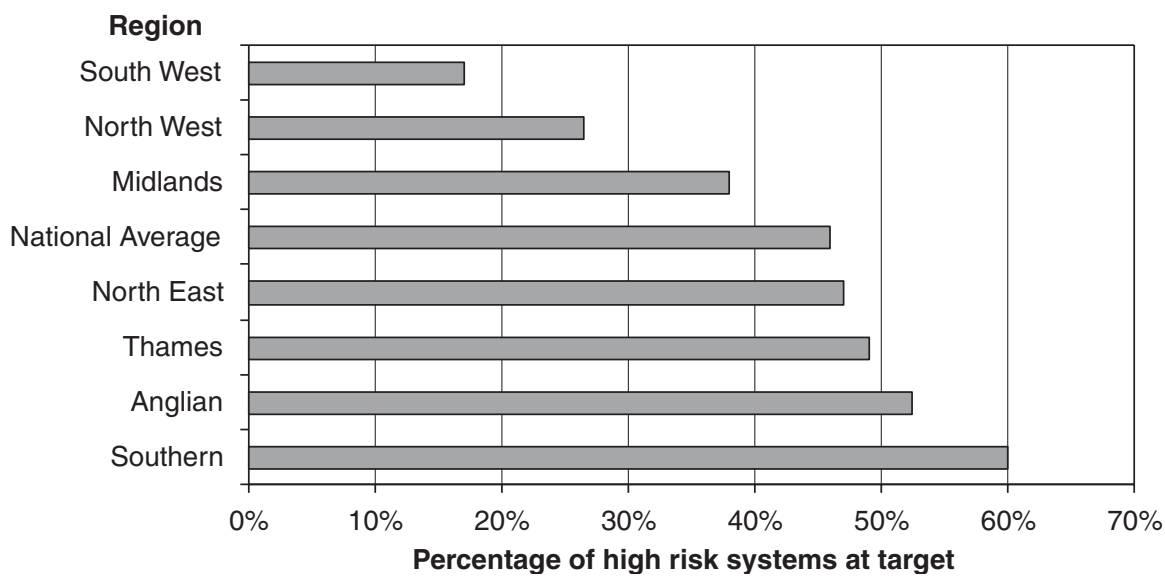

Figure 2: Percentage of high-risk systems at target condition in 2007

Source: House of Commons Committee of Public Accounts 
which schemes do get approval with the limited amount of money allocated to new flood defence schemes each year, 'a drop in the ocean' at only $£ 20.2 \mathrm{~m}$ in 2007-2008, Pitt (2007, p. 55) states:

'the Government has developed prioritisation approaches that aim to provide a fair and transparent means of distributing investment to get best value across a wide range of projects'.

The National Audit Office, however, provides a more contrasting assessment:

'The existing scoring system does tend to disadvantage smaller communities prone to frequent flooding, however, as the relatively small number of households will score less than larger urban areas'. (National Audit Office, 2007, p. 37)

\section{MEASURES AVAILABLE TO REDUCE THE IMPACT OF FUTURE FLOODING ON DOMESTIC HOUSING}

There are ultimately two main approaches to mitigate the impacts of future flooding on existing domestic housing, namely improving its flood resistance and/or its flood resilience. The principle aim of flood resistance is to prevent the ingress of floodwaters into a building in the first instance and thus prevent damage to the building fabric altogether. This can be achieved in two ways:

(i) A permanent or temporary flood barrier preventing floodwater from entering the curtilage of a building.

(ii) The use of temporary flood protection products (ie flood skirts, air brick covers, oneway drainage valves, etc) and other practical measures (ie 'tanking' of the external walls) to provide a watertight envelope that restricts the passage of any floodwaters from getting inside the building itself through entry routes such as permeable brickwork or weathered/damaged mortar joints, air bricks, gaps and cracks in joint sealant around doors and windows, backflow through overloaded drainage/sewage systems and entry through breaches in the envelope for the passage of services such as pipes and cables.

The role of permanent flood barriers has been previously discussed. There has been an influx of temporary flood protection products in the UK, aimed at improving a property's resistance to floodwaters since the autumn 2000 floods. These include freestanding flood barriers, air brick covers, door guards and one-way drainage valves, among many others.

Flood protection products perform well at keeping water out of buildings during shallow floods and will provide extended periods to allow occupiers to move possessions from the ground floor to safer heights during deeper floods (ABI, 2007c). Performance, however, is questioned during sustained exposure to floodwaters where water will eventually penetrate porous masonry walls and floors - albeit a 'cleaner' floodwater as the majority of silt and debris remain outside the property (ABI, 2007c). Furthermore, the products should not be used where flood depths exceed $0.3 \mathrm{~m}$. At these levels, the products will magnify the differential head exerted upon a buildings' structure and potentially cause structural damage (DEFRA 2007). For these reasons, the integration of flood resilient repairs/measures may have to be considered in order to reduce the impacts of flooding on domestic property.

Flood resilience accepts that floodwaters will breach the external envelope of a building, but its impact on a property will be minimised by improving the ability of construction components to recover from flooding (Garvin et al., 2005). This 
subsequently reduces the damage caused by a flood, reduces the cost of remediation and facilitates the drying process and time of reoccupation. The measures concern various components of domestic property including floors (ie replace suspended timber floors with solid concrete floors), walls (ie replace gypsum-based plasterboards with cementitious wallboards fixed as necessary with either non-corrosive fixings or water repellent adhesive), internals (ie replace timber skirting boards, architraves and door frames with glass reinforced plastic or fully treated timber) and services (ie mount boilers above the highest likely level of a future flood). These measures are commonly integrated as part of the repair following a flood, but 'could be installed in anticipation of damage if required, or during refurbishment' (Proverbs and Soetanto, 2004, p. 14) - for example, the works carried out by social housing providers to comply with the Decent Homes Standard. A thorough making-safe, drying and decontamination process should be completed before a post-flood survey and specified flood resilient repair work is carried out (Garvin et al., 2005).

The extra costs of implementing flood resilient repairs over like-for-like repairs are easily recuperated after a single flood event. The effectiveness of flood resilient measures can be gauged from a case study carried out in The Pitt Review where a householder was out of their home for seven months during the floods of 2000. Increased flood resilience was implemented during subsequent remedial works through choice of building materials, repositioning of services and the replacement of a timber ground floor with a solid concrete ground floor. The same property flooded again in 2007 and the householder was back in their home within four weeks.

\section{Uptake of flood resistant and flood resilient measures}

'Despite the evident benefits of these measures, their uptake is not high' (Pitt, 2007, p. 43). Research commissioned by the ABI identified that 85 per cent of its 2012 respondents acknowledged future flood risk affecting the UK, yet only 57 per cent believed that individuals had a key role in guarding against flood risk, and only ' 6 per cent said they would use resistant or resilient materials and products' (Pitt, 2007, p. 43).

The Office of Science and Technology (2002, p. 3) identifies that many individuals cannot afford to invest in temporary flood defence products:

'Participants felt that the cost of flood protection aids prohibited many individuals from being able to take steps to protect their homes'. (Office of Science and Technology, 2002, p. 3)

The increase in availability of such products has been complimented by the introduction of a 'Kite mark' scheme operated by the British Standards Institute to regulate their quality (Broadbent, 2004). The quality of these products, however, may be limited, judging by the view of Proverbs and Soetanto (2004, p. 14) — 'so far very few have been granted approval'. By contrast, Parrett (2006) argues that these products are likely to be far more effective than the widely used sandbag that performs poorly in comparison at withholding floodwaters away for a period of time and are a source of harmful contaminants post-flood. In spite of these inadequacies, the use of sandbags in a flood event is crystallised in the minds of the UK public. The fact that 2.5 million were used in the 2000 floods by the EA (Environment Agency, 2001) and information provided by both the EA and many local authorities on preparing for flood events still contains 'make sandbags using old pillow cases' (Mullen, 2008) reinforces this theory.

In relation to flood resilient measures, Pitt (2007) argues that there is little incentive to repair flood-damaged properties with resilient materials since insurance companies refuse 
to pay for betterment. The source goes on to describe a case where an insurance company classified moving a fuse box higher as betterment. Yet it is evident that the cost difference between using like-for-like repairs and some resilient repairs is negligible, that is using cementitious boards instead of gypsum plasterboard and 'resilient doors would be approximately the same cost as standard doors' (Bowker, 2007, p. 40). It is, however, accepted that flood resilient measures will generally cost more and this is supported by a cost analysis conducted by Bowker (2007), which shows that there is a 32 per cent cost increase between reinstating a room as it was originally and reinstating the same room with flood resilient measures.

\section{CONCLUSIONS}

There is an overwhelming body of evidence to suggest that climate change caused by global warming is causing more frequent and more intense rainfall, and hence an increased risk of flooding. Ambitions to build a further three million homes in the UK will undoubtedly increase greenhouse gas emissions in the UK, no matter how sustainable the development is, and thus will enhance the climate change - flood risk scenario. It has also been identified that other variables apart from climate change such as poor condition of flood defences, increased development of flood risk sites and potentially ineffective and contrasting planning policy are amplifying this risk.

The devastating impacts of a flood event upon both property and people have been determined - further magnified for the socially disadvantaged. There are currently significant proportions of the UK housing stock that are at risk or will be at risk of future flooding. It is impossible to retrospectively apply PPS 25 and therefore a variety of flood resistant and flood resilient methods have been developed to aid and assist owners who may find their property at risk of flooding. The benefits and constraints of these measures have been identified in the review. Despite their obvious advantages, however, previous research illustrates that the uptake of these measures is relatively poor and an overreliance upon ineffective sand bags is cemented in the forefront of the public's mind. It is proffered that inferior quality and extra costs associated with the measures are the main stumbling blocks to a wider uptake.

\section{References}

ABI. (2003) Development Planning and Flood Risk (PPG 25): Association of British Insurers Guidance on Insurance Issues [online]. Association of British Insurers, London, available at http://www.abi.org.uk/Display/File/78/ PPG25guidance2.pdf, accessed 22nd March, 2008.

ABI. (2007a) Summer Floods 2007: Learning the Lessons [online], Association of British Insurers, London, available at http://www.abi.org.uk/BookShop/ResearchReports/Flooding\%20in\%20the\%20UK\%20Full.pdf, accessed 21st March, 2008.

ABI. (2007b) Access for All: Extending the Reach for Insurance Protection [online], Association of British Insurers, London, available at http://www.abi.org.uk/BookShop/ResearchReports/Access\%20All\%20Areas\%20v4.pdf, accessed 22nd March, 2008.

ABI. (2007c) Flood Resilient Homes: What Homeowners can do to Reduce Flood Damage [online], Association of British Insurers, London, available at http://www.abi.org.uk/Display/File/Child/553/Flood_Resilient_Homes.pdf, accessed 17th February, 2008.

BBC News. (2007a) 2007 'probably UK wettest summer' [online], The BBC, available at http://news.bbc.co.uk/1/hi/ uk/6971370.stm, accessed 22nd October, 2007.

BBC News. (2007b) 'Severe trauma' of flood victims [online], The BBC, available at http://news.bbc.co.uk/1/hi/ england/7143959.stm, accessed 22nd March, 2008.

Bowker, P. (2007) Flood Resistance and Resilience Solutions: An R\&D Scoping Study, Department for Environment, Food and Rural Affairs, London. 
Broadbent, C. (2004) 'Improving the flood resistance of domestic property', Structural Survey, 22(2), 79-83.

Channel 4. (2007) Floods: The Year Britain Went Under [TV], Channel 4, 27th December.

Channel 4. (2008) Britain's Worst Weather [TV], Series 1 Episode 1: Floods, Channel 4, 6th January.

Channel 4 News. (2007) FactCheck: flood spending cut? [online], available at http://www.channel4.com/news/articles/ society/environment/factcheck+flood+spending+cut/622582, accessed 12th February, 2008.

DCLG. (2006) Planning Policy Statement 2 [online], Department for Communities and Local Government, London, available at http://www.communities.gov.uk/documents/planningandbuilding/pdf/planningpolicystatement25., accessed 17th February, 2008.

DCLG. (2007) Homes for the Future: More Affordable, More Sustainable, Department for Communities and Local Government, The Stationary Office, London.

DEFRA. (2001) DEFRA FD2304 Final Report (CEH Wallingford \& the Met Office): To what degree can the October/ November 2000 flood events be attributed to climate change? [online], The Department for Environment Food and Rural Affairs, London, available at http://www.defra.gov.uk/environ/fcd/floodincidents/fd2304fr.pdf, accessed 4th March, 2008.

DEFRA. (2007) Flooding in England, June/July 2007: general Q\&A factsheet [online], Department for Environment, Food and Rural Affairs, London, available at http://www.defra.gov.uk/environ/fcd/floods07/floodQA.pdf, accessed 15th October, 2007.

Department of Trade and Industry (DTI). (2007) Meeting the Energy Challenge A White Paper on Energy, The Stationary Office, London.

DETR. (2000) Quality and Choice: A Decent Home for All: The Housing Green Paper - Summary, Department of the Environment, Transport and the Regions, London.

Environment Agency. (2001) Lessons Learned: Autumn 2000 Floods, Environment Agency, Bristol.

European Commission. (2006) Memo: Saving 20\% by 2020 [online], European Commission Directorate-General for Energy and Transport, available at http://ec.europa.eu/energy/action_plan_energy_efficiency/doc/memo_en.pdf, accessed 21st February, 2008.

Fowler, H. (2006) 'Extreme rainfall' incidents increasing in parts of U.K [online], Newcastle University, Newcastle, available at http://www.ncl.ac.uk/press.office/press.release/content.phtml?ref=1157358561, accessed 2nd November, 2007.

Garvin, S., Reid, J. and Scott, M. (2005) Standard for the Repair of Buildings Following Flooding, CIRA Publication C623, London.

Gray, R. (2007) Hull council had no flood insurance [online], Telegraph Media Group Limited, available at http://www. telegraph.co.uk/news/main.jhtml?xml=/news/2007/07/22/nflood422.xml, accessed 19th October, 2007.

Harriott, S. and Mathews, L. (2004) Introducing Social Housing: Housing Policy and Practice Series, The Chartered Institute of Housing, Coventry.

HMSO. (2004) A Review of Housing Supply: Delivering Stability: Securing our Future Housing Needs: Final Report Recommendations, Her Majesty's Stationary Office, Norwich.

House of Commons Committee of Public Accounts. (2007) Environment Agency: Building and Maintaining River and Coastal Flood Defences in England, The Stationary Office Limited, London.

Hull City Council. (2008) Future planning — Thinking ahead [online], Hull City Council, Hull, available at http://www. hullcc.gov.uk/portal/page?_pageid=221,505688\&_dad=portal\&_schema=PORTAL., accessed 22nd March, 2008.

King, D. (2004) Foresight Future Flooding Report, Office of Science and Technology, London.

Met Office. (2000) Great weather events: U.K. flooding in 2000 [online], Met Office, available at http://www.metoffice. gov.uk/corporate/pressoffice/anniversary/flood2000.html, accessed 15th March, 2008.

Met Office. (2007) News release: record breaking rainfall figures [online], Met Office, available at http://www.metoffice. gov.uk/corporate/pressoffice/2007/pr20070726.html, accessed 22nd October, 2007.

Mullen, R. (2008) Flooding: preparing for a flood factsheet [online], The Environment Agency, available at http://www.environment-agency.gov.uk/subjects/flood/826674/882909/167259/167280/, accessed 1st April, 2008.

National Audit Office. (2007) Environment Agency: Building and Maintaining River and Coastal Defences in England, The Stationary Office, London.

Office of Science and Technology. (2002) Postnote Number 177: Floodforum.Net - An Online Discussion [online], Office of Science and Technology, London, available at http://www.parliament.uk/post/pn177.pdf, accessed 17th February, 2008. 
OPDM. (2004) The Planning Response to Climate Change [online], Office of the Deputy Prime Minister, London, available at http://www.communities.gov.uk/documents/planningandbuilding/pdf/147597, accessed 17th February, 2008.

Parrett, M. (2006) Mike Parrett's Guide to Building Pathology: Flooding [DVD] Limelite Media Limited, London.

Pitt, M. (2007) Learning Lessons from the 2007 Floods: An Independent Review by Sir Michael Pitt, Cabinet Office, London.

Pound, J. (2007) What does the Foresight report show? [online], Environment Agency, available at http://www. environment-agency.gov.uk/subjects/flood/763964/?version=1\&lang=_e, accessed 2nd November, 2007.

Proverbs, D. (2007) Flood expert warns of delays for property experts [online], University of Wolverhampton, Wolverhampton, available at http://www.wolverhampton.ac.uk/Default.aspx?page=14240, accessed 22nd March, 2008.

Proverbs, D. and Soetanto, R. (2004) Flood Damaged Property: A Guide to Repair, Blackwell Publishing Limited, Oxford.

Sheffield Forum. (2007) Sheffield Flood Fund - Where Is It? [online], available at http://www.sheffieldforum.co.uk/ showthread.php? $=3108093$, accessed 22nd March, 2008.

Soetanto, R., Proverbs, G.D. and Nicholas, J. (2002) RICS Foundation construction and building research conference, The Royal Institution of Chartered Surveyors, Nottingham Trent University, available at http://www.rics.org/NR/ rdonlyres/9C05644F-F0AF-46AC-910D-20B24BD23AE3/0/assessment_of_flood_damage_20020116.pdf, accessed 28th October, 2007.

The Decent Homes Standard. (2008) About Decent Homes [online], The Decent Homes Standard, available at http://www.decenthomesstandard.co.uk/about, accessed 22nd March, 2008.

The Independent. (2007) Government urged to 'wake up' on flooding insurance [online], The Independent, available at http://www.independent.co.uk/money/insurance/government-urged-to-wake-up-on-flooding-insurance-763926.html, accessed 1st March, 2008.

The Parliamentary Office of Science and Technology. (2000) Post Note 151 The Autumn 2000 Rains and Floods [online], The Parliamentary Office of Science and Technology, London, available at http://www.parliament.uk/ post/pn151.pdf, accessed 22nd October, 2007.

Thompson, D. (ed) (1996) The Concise Oxford Concise Dictionary, Oxford University Press, London.

Wilson, G. (2007) New homes will be built on flood plains [online], Telegraph Media Group Limited, available at http:// www.telegraph.co.uk/earth/main.jhtml?xml=/earth/2007/07/23/eagreen123.xml, accessed 4th March, 2008.

Womack, S. (2007) Plight of flood victims goes on [online], Financial Mail, available at http://www.thisismoney.co.uk/ insurance/household-insurance/article.html?in_article_id=427166\&in_page_id=34, accessed 22nd March, 2008.

Wright, I. (2007) Written answers in House of Commons debate, available from http://www.publications.parliament.uk/ $\mathrm{pa} / \mathrm{cm} 200607 / \mathrm{cmhansrd} / \mathrm{cm} 070724 / \mathrm{text} / 70724 \mathrm{w0007.htm \# 070724109000671.}$ 